\title{
Prevalensi trematodiasis pada sapi bali di Kupang dengan pemeriksaan feses metode filtrasi
}

\author{
Aji Winarso*, Nadia D. Kale, Diana M. Rihi, Desmond T.M. Hurek, Poppy S. Pello, Venansia N. \\ Beti, Maria M. Moi, Mesa J.N. Boru, Rizky Y. Manafe, Maria D.E. Parera, Maria Gratsia M. Jo, \\ Yohanes R. Nadja, Dalmasia T. Dhiu, Mario Cantona, Lucia D. Amleni, Sharoniva J. Koanak, \\ Yusinta V. Nawa, Angela N. Daki, Jeanet F.T.L. Pora
}

Fakultas Kedokteran Hewan, Universitas Nusa Cendana, Kota Kupang, Nusa Tenggara Timur

\begin{abstract}
ABSTRAK: Pengendalian yang strategis perlu mempertimbangkan data epidemiologi trematodosis itu sendiri. Penelitian ini bertujuan untuk mengetahui status prevalensi terkini (update) kasus trematodosis pada sapi bali di Kupang. Sebanyak 51 ekor sapi bali dewasa diambil sampel feses dan diperiksa dengan metode filtrasi bertingkat selama periode September 2019 hingga Januari 2020. Data diolah dan ditampilkan sebagai statistik deskriptif. Kajian ini mengungkap prevalensi trematodosis pada sapi bali di Kupang sebesar 25,49\%, dengan diantaranya menderita fasciolosis sebesar 19,61\% dan infeksi amphistome sebesar $9,80 \%$.
\end{abstract}

\section{Kata kunci:}

Fasciola, filtrasi bertingkat, Paramphistomum, semi-arid tropis, trematoda

\section{- PENDAHULUAN}

Trematodosis merupakan penyakit utama dan umum dijumpai pada sapi di seluruh dunia (Fromsa et al. 2011). Trematodosis pada ternak menimbulkan kerugian ekonomi karena menurunkan produktivitas ternak (Satyawardana 2018). Cacing trematoda menyebabkan kerugian ekonomi yang besar berupa penurunan bobot ternak, bobot karkas, produksi daging, produksi susu, serta pengafkiran organ yang tidak layak konsumsi dan biaya pengobatan (Jaja et al. 2017). Infeksi Fasciola sp. yang menyerang liver juga berimbas pada penurunan metabolisme lemak, protein dan karbohidrat sehingga penyerapan makanan terganggu, gangguan pertumbuhan, anemia, dan pada beberapa kasus dapat berakibat fatal (Hambal et al. 2013).

Arsani et al. (2015) menyatakan bahwa Fasciola sp. dan Paramphistomum sp. adalah spesies trematoda yang umum ditemukan di Indonesia. Pengendalian yang strategis perlu mempertimbangkan data epidemiologi trematodosis itu sendiri. Oleh karena itu, penelitian ini bertujuan untuk mengetahui status prevalensi terkini kasus trematodosis pada sapi bali di Kupang, Nusa Tenggara Timur.

\section{- BAHAN DAN METODE}

Penelitian ini merupakan kajian cross sectional dengan jumlah sampel sebanyak 51 ekor sapi bali dewasa (di atas 2 tahun). Koleksi sampel feses per-rektal dari sapi bali dilakukan di RPH Oeba Kota Kupang. Sampel feses sapi tersebut kemudian diperiksa dengan metode kualitatif filtrasi bertingkat (diameter mesh berturut-turut $400 \mu \mathrm{m}, 100 \mu \mathrm{m}$ dan $45 \mu \mathrm{m}$ ) dibantu pewarnaan biru metilen (Winarso 2019) di
Laboratorium Parasitologi Fakultas Kedokteran Hewan Universitas Nusa Cendana. Kajian ini dilaksanakan pada selang September 2019 hingga Januari 2020. Hasil pemeriksaan dicatat dalam tabel pengamatan sebagai hasil positif dan negatif, kemudian data diolah dan ditampilkan sebagai statistik deskriptif.

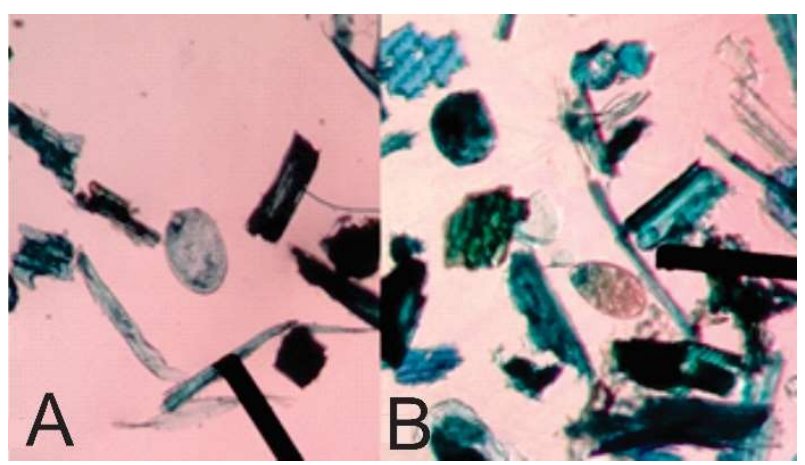

Gambar 1 Temuan telur trematoda dengan teknik filtrasi bertingkat: A. telur amphistome, B. telur Fasciola.

\section{- HASIL DAN PEMBAHASAN}

Hasil pengamatan sampel feses menunjukkan adanya temuan telur amphistome dan telur Fasciola (Gambar 1). Telur amphistome yang ditemukan sangat mungkin adalah dari genus Paramphistomum. Paramphistomum adalah amphistome yang paling umum dijumpai pada sapi dan

Diterima: 11-01-2021 | Direvisi: 17-02-2021 | Disetujui: 19-02-2021 (C) 2021 CC-BY-SA. Ini adalah artikel Open Access yang didistribusikan berdasarkan ketentuan dari Creative Commons Attribution ShareAlike 4.0 International License (https://creativecommons.org/licenses/by-sa/4.0/). 
ruminansia lainnya (Aragaw \& Tilahun 2018), meskipun di Indonesia ada spesies amphistome yang lebih jarang, yaitu Orthocoelium indonesiense (Eduardo 1980). Sedangkan untuk telur Fasciola yang ditemukan, dapat dipastikan adalah Fasciola gigantica, meskipun ada dua spesies Fasciola yang diketahui menginfeksi ruminansia dan manusia yaitu Fasciola hepatica dan Fasciola gigantica (Pfukenyi et al. 2005). Fasciola gigantica adalah satusatunya species yang bisa ditemukan di Indonesia dan banyak negara beriklim tropis lainnya (Purwaningsih et al. 2017; Degheidy \& Al-Malki 2012).

Prevalensi dari infeksi Fasciola dan amphistome secara rinci disajikan pada Tabel 1. Prevalensi trematodosis keseluruhan adalah 25,49\%. Adanya infeksi campuran sebesar $3,92 \%$ menunjukkan bahwa prevalensi fasciolosis yang terdeteksi sesungguhnya adalah $19,61 \%$ dan prevalensi infeksi amphistome sebesar 9,80\%.

Tabel 1 Prevalensi infeksi tunggal dan koinfeksi oleh trematoda pada sapi bali

\begin{tabular}{lcc}
\hline Infeksi Trematoda & $\begin{array}{c}\text { Jumlah positif } \\
\text { (Prevalensi) }\end{array}$ & $\begin{array}{c}\text { Frekuensi } \\
\text { Kumulatif }\end{array}$ \\
\hline Fasciola & $8(15,69 \%)$ & $15,69 \%$ \\
Paramphistomum & $3(5,88 \%)$ & $21,57 \%$ \\
Koinfeksi & $2(3,92 \%)$ & $25,49 \%$ \\
Negatif & $38(74,51 \%)$ & $100,00 \%$ \\
\hline
\end{tabular}

Prevalensi trematodosis di daerah beriklim tropis basah dilaporkan lebih tinggi, misalnya di Jogjakarta sebesar 50\% dengan rincian $48 \%$ untuk fasciolosis dan $47 \%$ untuk paramphistomiasis (Rinca et al. 2019). Perbedaan ini diduga berkaitan dengan perbedaan klimat antara Jogjakarta yang memiliki curah hujan lebih tinggi daripada wilayah Nusa Tenggara Timur, khususnya Pulau Timor yang beriklim semi-arid tropis. Risiko infeksi trematoda yang lebih tinggi pada daerah beriklim basah berkaitan dengan keberadaan siput sebagai inang antara trematoda. Area dengan curah hujan tinggi cocok untuk habitat siput dan juga cocok untuk perkembangan stadium pra-parasitik dari trematoda. Sebaliknya, temperatur yang tinggi, kelembapan yang rendah dan paparan sinar matahari langsung pada wilayah semi-arid mengurangi viabilitas metaserkaria (Pfukenyi et al. 2005).

Prevalensi fasciolosis yang ditemukan pada kajian ini sedikit lebih tinggi daripada laporan sebelumnya pada pemeriksaan post-mortem terhadap sapi potong di Rumah Potong Hewan Oeba Kota Kupang yang memiliki prevalensi sebesar 17.19\% (Damayanti et al. 2019). Paparan tertinggi pada daerah semi-arid seperti Kupang adalah pada awal musim kemarau, ketika rendaman air pada hijauan mulai surut dan menguak metaserkaria pada bagian bawah tanaman (Chongmobmi \& Panda 2018). Pada saat tersebut, viabilitas metaserkaria yang masih baik bertepatan dengan kelangkaan hijauan mengakibatkan sapi memakan bagian bawah tanaman. Hal yang sama terjadi ketika sapi memakan bagian bawah tanaman padi sisa panen yang terendam air pada musim hujan. Semakin banyak paparan metaserkaria, maka derajat infeksinya semakin berat. Menurut Aragaw dan Tilahun (2018), infeksi trematoda moderat dan fasciolosis kronis dapat menyebabkan rendahnya body condition score.

\section{- SIMPULAN}

Prevalensi trematodosis pada sapi bali di Kupang sebesar $25,49 \%$, dengan diantaranya menderita fasciolosis sebesar $19,61 \%$ dan infeksi amphistome sebesar 9,80\%.

\section{- INFORMASI PENULIS}

\section{Penulis Korespondensi}

*AW: ajiwinarso@staf.undana.ac.id

Fakultas Kedokteran Hewan, Universitas Nusa Cendana

\section{- UCAPAN TERIMA KASIH}

Terima kasih kepada Prodi PPDH FKH Universitas Nusa Cendana, UPT RPH Oeba dan Dinas Pertanian Kota Kupang untuk izin pengambilan sampel.

\section{- PUSTAKA ACUAN}

Aragaw K, Tilahun H. 2018. Coprological study of trematode infections and associated host risk factors in cattle during the dry season in and around Bahir Dar, Northwest Ethiopia. Veterinary and Animal Science. 7: 100041

Chongmobmi M, Panda SM. 2018. Bovine Gastrointestinal Trematodosis In Nigeria: A Review. IOSR Journal of Agriculture and Veterinary Science. 11(11): 08-19.

Damayanti LPE, Almet J, Detha AIR. 2019. Deteksi dan prevalensi fasciolosis pada sapi bali di Rumah Potong Hewan ( RPH ) Oeba Kota Kupang. Jurnal Veteriner Nusantara. 2(1): 13-18.

Degheidy NS, Al-Malki JS. 2012. Epidemiological studies of fasciolosis in human and animals at Taif, Saudi Arabia. World Applied Sciences Journal. 19(8): 1099-1104.

Eduardo SL. 1980. Orthocoelium indonesiense, a new species of amphistome from ruminants in Indonesia. Systematic Parasitology. 1: 203-210.

Fromsa A, Meharenet B, Mekibib B. 2011. Major Trematode Infections of Cattle Slaughtered at JimmaMunicipality Abattoir and the Occurrence of the Intermediate Hosts in Selected Water Bodies of the Zone. Journal of Animal and Veterinary Advances.10(12):1592-1597.

Hambal M, Arman S, Agus D. 2013. Tingkat Kerentanan Fasciola gigantica pada Sapi dan Kerbau di Kecamatan Lhoong Kabupaten Aceh Besar. Jurnal Medika Veterinaria. 7(1): 49-53.

Jaja IF, Mushonga B, Green E, Muchenje V. 2017. Seasonal prevalence, body condition score and risk factors of bovine fasciolosis in South Africa. Veterinary and Animal Science. 4(6): 1-7.

Pfukenyi DM, Monrad J, Mukaratirwa S. 2005. Epidemiology of trematode infections in cattle in Zimbabwe: a review. Journal of the South African Veterinary Association. 76(1): 9-17.

Purwaningsih, Noviyanti, Putra RP. 2017. Distribusi dan Faktor Risiko Fasciolosis pada Sapi Bali di Distrik Prafi, Kabupaten Manokwari, Provinsi Papua Barat. Acta Veterinaria Indonesiana. 5(2): 120-126.

Rinca KF, Prastowo J, Widodo DP, Nugraheni YR. 2019. Trematodiasis occurrence in cattle along the Progo River, Yogyakarta, Indonesia. Veterinary World. 12(4): 593-597.

Satyawardana W, Ridwan Y, Satrija F. 2018. Trematodosis pada Sapi Potong di Wilayah Sentra Peternakan Rakyat Kecamatan Kasiman Kabupaten Bojonegoro. Acta Veterinaria Indonesiana. 6(2): 1-7.

Winarso A. 2019. Teknik Diagnosis Laboratorik Parasitologi Veteriner: Parasit Sistem Digesti. Blitar: Veterinary Indie Publisher. 